Development of Prayer Mobile Application Software for The Hearing Impaired (Deaf) Based on Malaysian Sign Language

Abdul Rahim Razalli, Nordin Mamat, Normah Razali, Mohd Hanafi Mohd Yasin, Modi Lakulu, Abdul Talib Mohamed Hashim \& Azli Ariffin

To Link this Article: http://dx.doi.org/10.6007/IJARBSS/v11-i6/10243 DOI:10.6007/IJARBSS/v11-i6/10243

Received: 11 April 2021, Revised: 13 May 2021, Accepted: 28 May 2021

Published Online: 15 June 2021

In-Text Citation: (Razalli et al., 2021)

To Cite this Article: Razalli, A. R., Mamat, N., Razali, N., Yasin, M. H. M., Lakulu, M., Hashim, A. T. M., \& Ariffin, A. (2021). Development of Prayer Mobile Application Software for The Hearing Impaired (Deaf) Based on Malaysian Sign Language. International Journal of Academic Research in Business and Social Sciences, 11(6), 1108-1122.

Copyright: (c) 2021 The Author(s)

Published by Human Resource Management Academic Research Society (www.hrmars.com) This article is published under the Creative Commons Attribution (CC BY 4.0) license. Anyone may reproduce, distribute, translate and create derivative works of this article (for both commercial and non-commercial purposes), subject to full attribution to the original publication and authors. The full terms of this license may be seen at: http://creativecommons.org/licences/by/4.0/legalcode

Vol. 11, No. 6, 2021, Pg. 1108- 1122

Full Terms \& Conditions of access and use can be found at http://hrmars.com/index.php/pages/detail/publication-ethics 


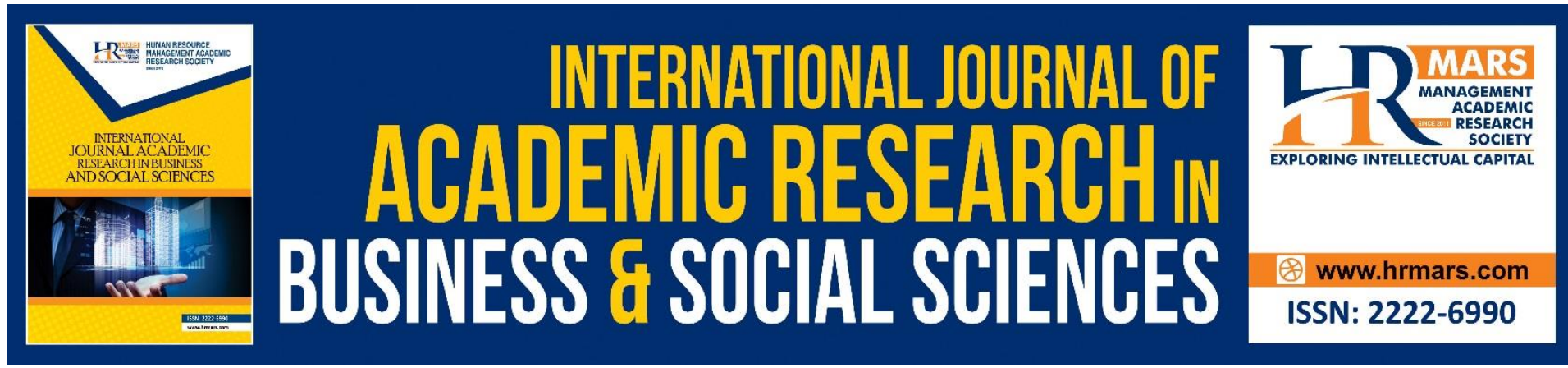

\title{
Development of Prayer Mobile Application Software for The Hearing Impaired (Deaf) Based on Malaysian Sign Language
}

\author{
Abdul Rahim Razalli, Nordin Mamat, Normah Razali, Mohd \\ Hanafi Mohd Yasin, Modi Lakulu, Abdul Talib Mohamed \\ Hashim \& Azli Ariffin \\ Faculty of Human Development, Sultan Idris Education University, 35900 Tanjong \\ Malim, Perak
}

\begin{abstract}
This study highlights on development of mobile prayer software for the hearing impaired community. The design and development research method (DDR) of this study is through instructional design model through five phases namely analysis, design, development, implementation and evaluation (ADDIE). The study sample involves 276 people consisting of deaf respondents, students with hearing impairments, teachers and experts in the field of information technology. The study identified that the software and design of the prayer mobile application for the hearing impaired users should include interactive features particularly graphics, animation, voice, video, text size and arrangement, as well as font size and colours. As for the design display, there are six elements should be given priority namely balanced topographic arrangement elements, bright theme divider, data divider, navigation, horizontal line layout and button section. Hence, the development of a mobile prayer application helps the special-need-users to perform their prayer obligation apart from increase their understanding on the Islamic Education component.
\end{abstract}

Keyword: Mobile Software, Prayer, Hearing Impaired and Malaysian Sign Language.

\section{Introduction}

Mukti (2000) in her work concedes that human learning and understanding can be enhanced through interactive means in a learning environment. ICT application software helps the students to increase their understanding and confidence in practising the prayers and recitations of solah. According to Miswan and Adnan (2015), the advantages of multimedia technology and multi-touch screens are key features that will engage children's interest to keep exploring. Yet most of the applications developed often face either one of two problems i.e. content that is featuring too much interactive graphics and animation features compared to educational materials, or overfilled with educational materials but presented in a stereotypical and unexciting manner. Interactive multimedia courseware is an initiative taken in adapting the use of computer technology in teaching and facilitation activities. The rationale in producing mobile applications that meet the needs of hearing impaired or deaf 
indivisuals is to support reformation in the national education, which is to utilize ICT to improve the quality of learning in Malaysia. Its rationale also meets the requirements of challenges in the fourth Industrial Revolution (4IR) which required digital technology -based learning. The use of mobile applications is a current learning trend (Hashim, et al., 2019 and Awang, et al.,2018). Technology in education must be integrated in the lives of deaf people for them to further improve their mastery and skills (Zainuddin, 2017). The features contained in the built-in mobile applications should also meet the needs of the special-need-users especially in content (Shraim, 2019). According to Ahmad el al., (2018), there are application softwares developed either in mobile and web-based mode or in the play store such as SaveME 999'I application that is designed for hearing and speech impaired users.

\section{Problem Statement}

A mobile application or mobile apps is a program that is loaded into a mobile device and it can be used anytime and anywhere to perform certain tasks for the users. A study by Nawi \& Hamzah (2013), found that the use of mobile applications in education is still at an early stage in Malaysia. According to Chan et al (2013) smartphone applications developed by individuals, business sectors, government agencies, military, and institutions are generally for purpose of entertainment, problem solving and meeting daily needs (Mamat et al., 2020). The mobile apps are mainly simple, user-friendly, and inexpensive in features. Although many applications have been increasingly developed recently, a study by Nawi \& Hamzah (2013) revealed that smartphone applications with Islamic characteristics, are still scarce in numbers compared to other applications. Islamic-based applications on mobile phones with the introduction of the Ilkone 1800 were the first Islamic -featured mobile devices developed (Wyche, et. al., 2008). Mobile application technologies that integrated Islamic and religious knowledge fields for various age groups are still few (Ismail et al., 2016). Review Razalli et al., (2019) found that only 65 applications designed for obligatory prayers, 30 apps for recitations in obligatory prayers and 16 apps for obligatory prayer in languages other than English, while no apps are available on prayer guide for the deaf.

Changes of role in teaching and learning are inevitable with the introduction of multimedia technology in education. Information has changed to digital mode likewise the educational curriculum has evolved with integration of multimedia and interactive elements to form a more engaging teaching and learning environment for both students and teachers. Incorporating multimedia in the classroom has become a global trend with strong support from the Malaysian government in incorporating technology in the classroom. Deaf students do not have auditory as well as speech senses but they can see and have good memory strength like mainstream students (Razalli, et al., 2015). It was also observed that teaching aids commonly used by Islamic education teachers is typically material developed for mainstream students that containing long description text, minimum visual illustration on prayer movements, and absence of sign language interpreters, or Malaysian Sign Language. Therefore, the development of mobile applications in Islamic education, in particular the practice of prayer should be made continuously through the use of blogs, social media, websites, applications on mobile phones such as WhatsApp and short message service (SMS). Such applications are among the examples of how this technology is manipulated in educational setting. Skills in using and understanding sign language are the two key elements that need to be given the emphasis in developing mobile applications for deaf users. Sign language skills need to be mastered for better knowledge teaching to hearing impaired 
students (Aunola et al., 2006; Guardino, 2015). The content of Sign language used in mobile applications should consider the balance of between the sign language and Islamic Education. Sign language proficiency that is still far from satisfactory level will cause ineffective teaching and learning to hearing impaired students (Yasin et al., 2017).

\section{Literature Review}

The world today should consider Islamic Education as the foundation that underlies the progress of science and technology (Ahmad, 2014). Islam has placed the element of education at the uppermost position. The importance of Islamic education is emphasized in the first verse of the Qur'an to be revealed, namely surah al-'Alaq, verses 1-5 (Mubarakfuri, 2010). In response to its importance, the subject of Islamic Education has been included in the national education system and has become a compulsory subject for all Muslim students (Ahmad, 2014). The Islamic Education Curriculum introduced in Malaysian education system helps to foster Muslim identity in accordance with Islamic law. It is a subject obligatory to every Muslim student, whether they are in primary school, secondary school or in institutes of higher learning. The Islamic Education Curriculum covers various fields such namely Aqeedah, Shari'ah, Akhlaq, 'Ibadah and Sirah. Such important topics help to strengthen Muslim personality of the students if they really embrace the lessons. Learning theory and learning strategies need to be considered to develop good and quality ICT-assisted application software. Additionally, both aspects help the teachers to achieve their teaching goals and to keep their students' attention on topics contained in the application software.

Graphics are the key development block in multimedia design (Vilamil-Casanova \& Molina, 1997). The software starting features are appealing with the use of graphic, color and animation elements to increase and maintain interest of the students in learning. Some of the software elements that help to create fun learning concept include the use of multimedia elements or certain icons that serve to provide information, assistance and guidance to users on using the software. For example, video for translator needs to be clicked if students need to use sign language for better understanding on text description available on the application software. The presentation process of the software will increase motivation of students to stay focus in learning. It was observed that the major problem commonly faced by lowachieving students is to recall important information. They also argued that the problem was related to short-term memory and it can be overcome through cognitive teaching strategies and methods. This problem can be solved through the use of ICT adaptation in particular the existence of mobile application software for teachers to help students master their thinking skills effectively. Also supported by Miswan and Adnan (2015), the advantages of multimedia technology and multi-touch screens are the key features that increase children's interest to continue exploring. Content can either be featuring too much interactive graphics and animations as opposed to educational material, or too loaded with educational material but presented in a stereotypical and unappealing manner.

The Design and Development Research Approach or known as (DDR) is a research concept on a development study in an organized and systematic manner. DDR is a systematic study that focuses on the product development process that involve analysis of the content and situation context, as well as evaluation of the product. The outcome of the product mainly refers to the model, technique, module or training program (Ujang, 2016). Richey \& Klein, (2007) stated that the Design and Development Research (DDR) approach is a highly 
organized study that includes the process of design, development and empirically based evaluation of an instructional product or vice versa and clarified that support technologies such as the use of mobile applications will enable the deaf community to follow the latest teaching and learning. In another study by Restituyo et al (2017), they found that mobile applications that contain pictures and video clips as well as feedback elements in sign language will improve the memorization and ability of deaf students. With the use of technology, this application software makes it more effective and helps to solve the existing problem. Mobile application is a program specially designed for smartphones to facilitate users in daily affairs and can be integrated with various fields of knowledge, especially Islamic elements (Ismail et al, 2016). While Sharples et.al, (2004) explained that the general need for appropriate m-learning technologies is to help the deaf students to use technology and communicate using mobile devices in real life. The technology also supports lifelong learning, and lists several advantages that can also be used to define effective practices in m-learning. The most effective courseware application approach is learning through instructional methods using equipment for instance using the computer software.

The ADDIE model is basically Analysis, Design, Development, Implementation, and Evaluation (Budoya et al., 2019). The structure of this model involves the stage of designing, developing and evaluating a product or module The ADDIE model is widely used in developing a product or module based on multimedia or technology (Zainuddin, 2017). While Design and Development Research (DDR) is an approach in developing a product or program specifically that involves processes in product and tool -based research (Siraj et al., 2013). The principles contained in DDR are absorbed and incorporated in the ADDIE model so that production and product development can be analyzed quantitatively for each phase. The use of Mobile Technologies for Students with Hearing Disability (IBEM) enables deaf people and hearing impaired individuals to communicate better and gain beneficial learning experiences (Cem Girgin et al, 2017). This study also helps to solve problems in teaching and facilitation. Mlearning is one of the latest types of learning that uses wireless network mobile technology, without time and place limitations, under autonomy level and limits determined by the device. Mobile technology offers a great opportunity for students as well as educators in the process of generating broad knowledge society. According to Ali (2014), this application assists deaf students to make notes and organize their works in school. Apart from that, this application has voice recording and playback features to record the lessons delivered. The recording and playback features enable them to convert the auditory lesson into written notes. Hence, this application is suitable with person with disabilities (PWD), meaning it is a PWD-user-friendly application.

GEOGRAFIA Online

TM

Malaysian Journal of Society and Space 10 issue 6 (86 - 96)

86

(C) 2014, ISSN 2180-2491

Salman A (2010) ICT, the new media (Internet) and development: Malaysian experience. The Innovation

Journal: The Public Sector Innovation Journal 15 (1), article 5. 


\section{Objectives}

To develop mobile prayer software for the hearing impaired community through the design and development (DDR) approach using instructional design model that comprises of five phases, namely analysis, design, development, implementation and evaluation (ADDIE).

\section{Research methodology}

In developing the Prayer Mobile Application Software for the Hearing Impaired (Deaf) based on Malaysian Sign Language, this study uses the ADDIE (1987) and Design and Development Research (DDR) models. The study sample involved 276 participants consisting of Special Education Teachers, Islamic Education Teachers, Islamic Education Special Education Teachers, Deaf People, Hearing Impaired Students, Special Education Specialists, Information and Application Technology Specialists, and Instructional Technology Specialists. The whole development process is as shown in the diagram below

Diagram I Framework for Prayer Mobile Application Software based on Malaysian Sign Language for Deaf Users

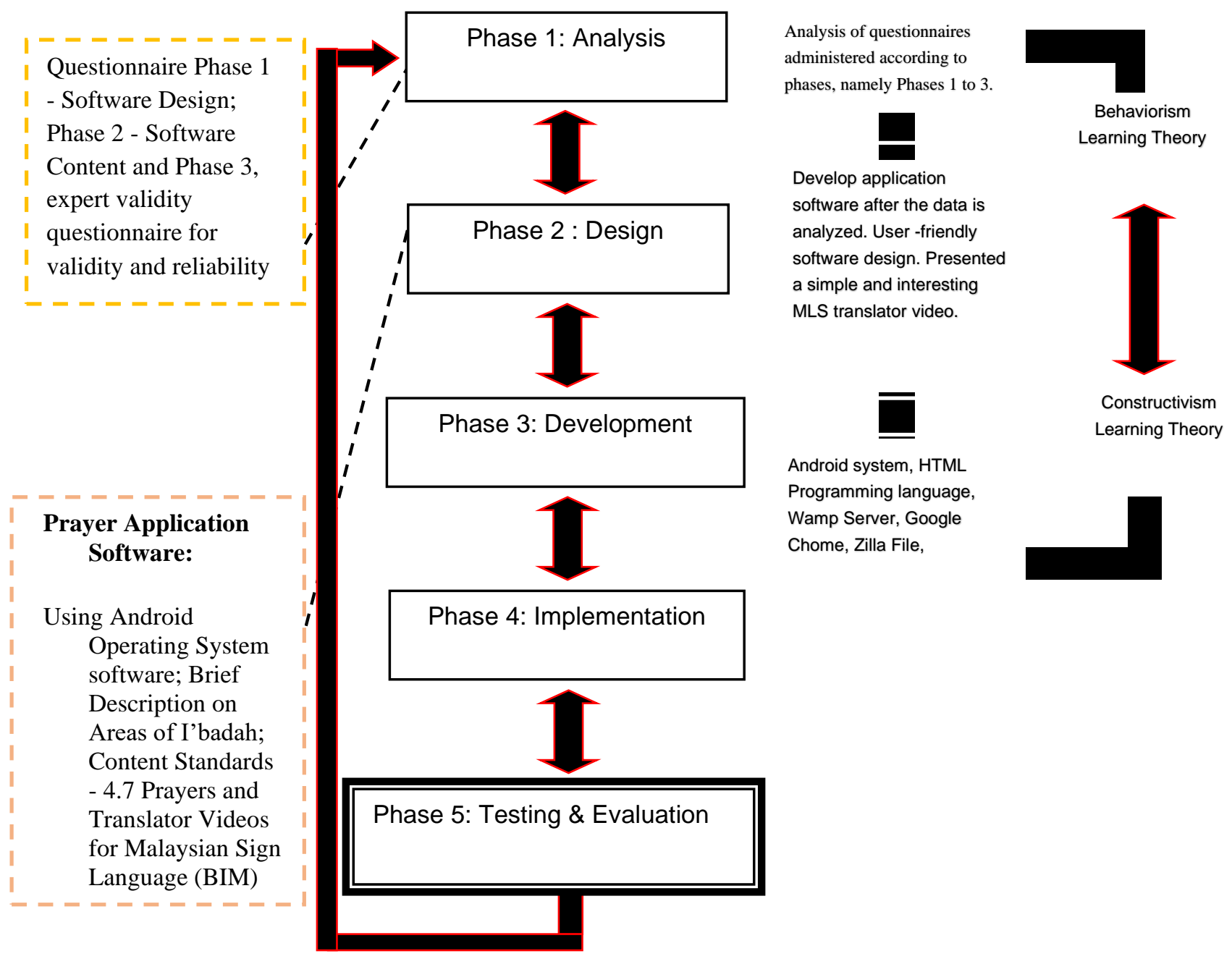




\section{Result and Discussion}

Table I Prayer Software Features and Application Design for Deaf Users

\begin{tabular}{|c|c|c|c|c|c|c|c|c|}
\hline \multirow[t]{2}{*}{ NO. } & \multirow[t]{2}{*}{ STATEMENT } & \multicolumn{5}{|c|}{$\begin{array}{c}\text { Scale and Percentage (\%) of } \\
\text { Agreement }\end{array}$} & \multirow[t]{2}{*}{$\begin{array}{c}\text { Mea } \\
\mathrm{n}\end{array}$} & \multirow[t]{2}{*}{ SD } \\
\hline & & $\begin{array}{c}1 \\
\text { SD }\end{array}$ & $\begin{array}{l}2 \\
D\end{array}$ & $\begin{array}{c}3 \\
\text { NS }\end{array}$ & $\begin{array}{l}4 \\
\mathrm{~A}\end{array}$ & $\begin{array}{c}5 \\
\text { SA }\end{array}$ & & \\
\hline A1. & $\begin{array}{l}\text { There is a combination of texts, } \\
\text { images, graphics, animation and } \\
\text { sound in this application software. }\end{array}$ & & & $\begin{array}{l}(47) \\
16.7\end{array}$ & $\begin{array}{c}(220 \\
1 \\
80.0\end{array}$ & $\begin{array}{l}(9) \\
3.3\end{array}$ & 3.86 & $\begin{array}{c}0.43 \\
4\end{array}$ \\
\hline A2. & $\begin{array}{l}\text { The combination of texts, images, } \\
\text { graphics, animation and sound in this } \\
\text { application software simplifies the } \\
\text { information delivery process. }\end{array}$ & & & $\begin{array}{l}(83) \\
30.0\end{array}$ & $\begin{array}{c}(184 \\
66.6\end{array}$ & $\begin{array}{l}(9) \\
3.3\end{array}$ & 3.70 & $\begin{array}{c}0.46 \\
6\end{array}$ \\
\hline A3. & $\begin{array}{l}\text { Multimedia elements such as texts, } \\
\text { images, graphics, animations and } \\
\text { voice make the learning environment } \\
\text { more enjoyable. }\end{array}$ & & & $\begin{array}{c}(55) \\
20\end{array}$ & $\begin{array}{c}(203 \\
73.3\end{array}$ & $\begin{array}{l}(18) \\
6.7\end{array}$ & 3.86 & $\begin{array}{c}0.50 \\
7\end{array}$ \\
\hline A4. & $\begin{array}{l}\text { Images, graphics, color text and } \\
\text { animations in this application } \\
\text { software can attract the students. }\end{array}$ & & & $\begin{array}{l}(46) \\
16.7\end{array}$ & $\begin{array}{c}(212 \\
76.7\end{array}$ & $\begin{array}{l}(18) \\
6.7\end{array}$ & 3.90 & $\begin{array}{c}0.48 \\
0\end{array}$ \\
\hline A5. & $\begin{array}{l}\text { The use of link buttons in this } \\
\text { application software makes it easy to } \\
\text { control the software during learning. }\end{array}$ & & & $\begin{array}{l}(92) \\
33.3\end{array}$ & $\begin{array}{c}175 \\
)_{63.3}\end{array}$ & $\begin{array}{l}(9) \\
3.3\end{array}$ & 3.70 & $\begin{array}{c}0.53 \\
4\end{array}$ \\
\hline A6. & $\begin{array}{l}\text { The screen display in this application } \\
\text { software is always consistent. }\end{array}$ & & & $\begin{array}{c}(55) \\
20\end{array}$ & $\begin{array}{c}(221 \\
80\end{array}$ & & 3.80 & $\begin{array}{c}0.40 \\
6\end{array}$ \\
\hline A7. & $\begin{array}{l}\text { The available interactive link buttons } \\
\text { allow users to easily explore this } \\
\text { Prayer Mobile Application Software. }\end{array}$ & & & $\begin{array}{c}(110 \\
40 \\
\end{array}$ & $\begin{array}{c}166 \\
60 \\
\end{array}$ & & 3.60 & $\begin{array}{c}0.49 \\
8\end{array}$ \\
\hline A8. & $\begin{array}{l}\text { The ease of navigating a screen } \\
\text { facilitates access to information. }\end{array}$ & & & $\begin{array}{c}(55) \\
20\end{array}$ & $\begin{array}{c}(221 \\
80\end{array}$ & & 3.80 & $\begin{array}{c}0.40 \\
6\end{array}$ \\
\hline A9. & $\begin{array}{l}\text { The screen design of the Prayer } \\
\text { Mobile Application Software display } \\
\text { is attractive and suitable for hearing } \\
\text { impaired Special Needs Pupils (SNS). }\end{array}$ & & & $\begin{array}{l}(64) \\
23.3\end{array}$ & $\begin{array}{c}(129 \\
) \\
46.7\end{array}$ & $\begin{array}{c}(83) \\
30\end{array}$ & 4.06 & $\begin{array}{c}0.73 \\
9\end{array}$ \\
\hline A10. & $\begin{array}{l}\text { This application software uses clear } \\
\text { and easy -to -read fonts. }\end{array}$ & & & $\begin{array}{c}(55) \\
20\end{array}$ & $\begin{array}{c}(212 \\
16.7 \\
7\end{array}$ & $\begin{array}{l}\text { (9) } \\
3.3\end{array}$ & 3.83 & $\begin{array}{c}0.46 \\
1\end{array}$ \\
\hline $1 \mathrm{~A} 1$. & $\begin{array}{l}\text { The graphics and images used in this } \\
\text { application software attract students } \\
\text { with special hearing needs to learn. }\end{array}$ & & & $\begin{array}{c}(138 \\
50\end{array}$ & $\begin{array}{c}(129 \\
) \\
46.7\end{array}$ & $\begin{array}{l}(9) \\
3.3\end{array}$ & 3.53 & $\begin{array}{c}0.57 \\
1\end{array}$ \\
\hline A12. & $\begin{array}{l}\text { The colors used in this application } \\
\text { software are suitable for students } \\
\text { with special hearing needs. }\end{array}$ & & & $\begin{array}{l}(74) \\
26.7\end{array}$ & $\begin{array}{c}(202 \\
1 \\
73.7\end{array}$ & & 3.73 & $\begin{array}{c}0.44 \\
9\end{array}$ \\
\hline
\end{tabular}




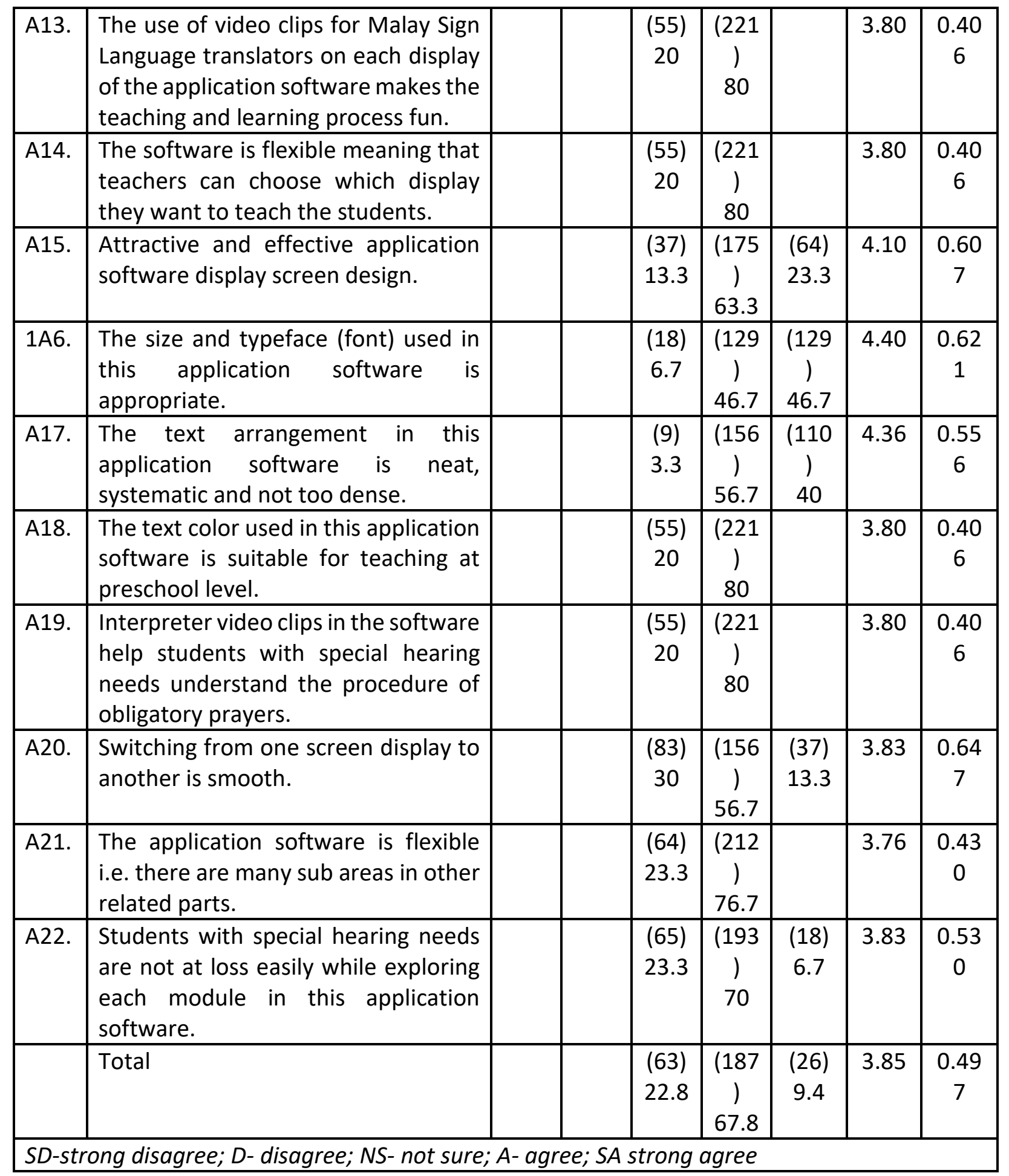

Findings from table I show the features of the software and design of the prayer mobile application for the hearing impaired (deaf) based on Malaysian Sign Language. There are 22 items that determine the design of deaf prayer application development, namely data division, topographic arrangement, buttons, colors, themes, theme dividers, letters, font size, layout, navigation, screen interaction and variety of information. The highest mean was recorded for item A16 which is mean $=4.40 ; \mathrm{sd}=0.621, \mathrm{~A} 17$ mean $=4.36 ; \mathrm{sd}=0.556$, and $\mathrm{A} 15$ mean $=4.10 ; s d=0.607$ or more than 85 percent agreed that the design aspects of size and font, text arrangement and screen design are given priority. The findings of this study are 
similar to the study by Mamat et al., (2020) that discovered the color selection of screen design in the development of multimedia applications has positive implications and helps students to understand the topics being taught. While Razalli et. Al (2015) accorded that on recent developments, the issue of multimedia message design in particular related to the integration of various media (such as graphics, audio, video, animation, text) became the main focus in studies related to the field of multimedia applications in education. In the same case, Mayer's study (2014) revealed that the use of multimedia had a better effect than the use of text, visual or voice alone. Overall, the study findings are at a high mean for software features and application design of prayer for the hearing impaired (deaf) with mean value $=$ 3.85; $\mathrm{sd}=0.497$ or 77.2 percent agreed that the mobile application developed should have a combination of texts, images, graphics, animation and voice. The video clips on sign language are supported with color, font size and interactive features. Furthermore, the study findings are similar to Embi (2016) work that highlighted the mobile application is a recent learning trend with all learning materials can be easily accessed by students through the use of smartphones. The internet accessed application can be done anywhere and anytime, thus changing the way students learn following the development of technology today. Application content design is similar to the study of Ali, (2014) that addressed the presentation process in application software can increase the motivation of students to continue using it. Some important elements featured in the software are intended to create an interesting learning atmosphere including the use of multimedia elements or icons specific that serves to provide information, assistance and guidance to the users in using the application.

TABLE II Display Design of Application

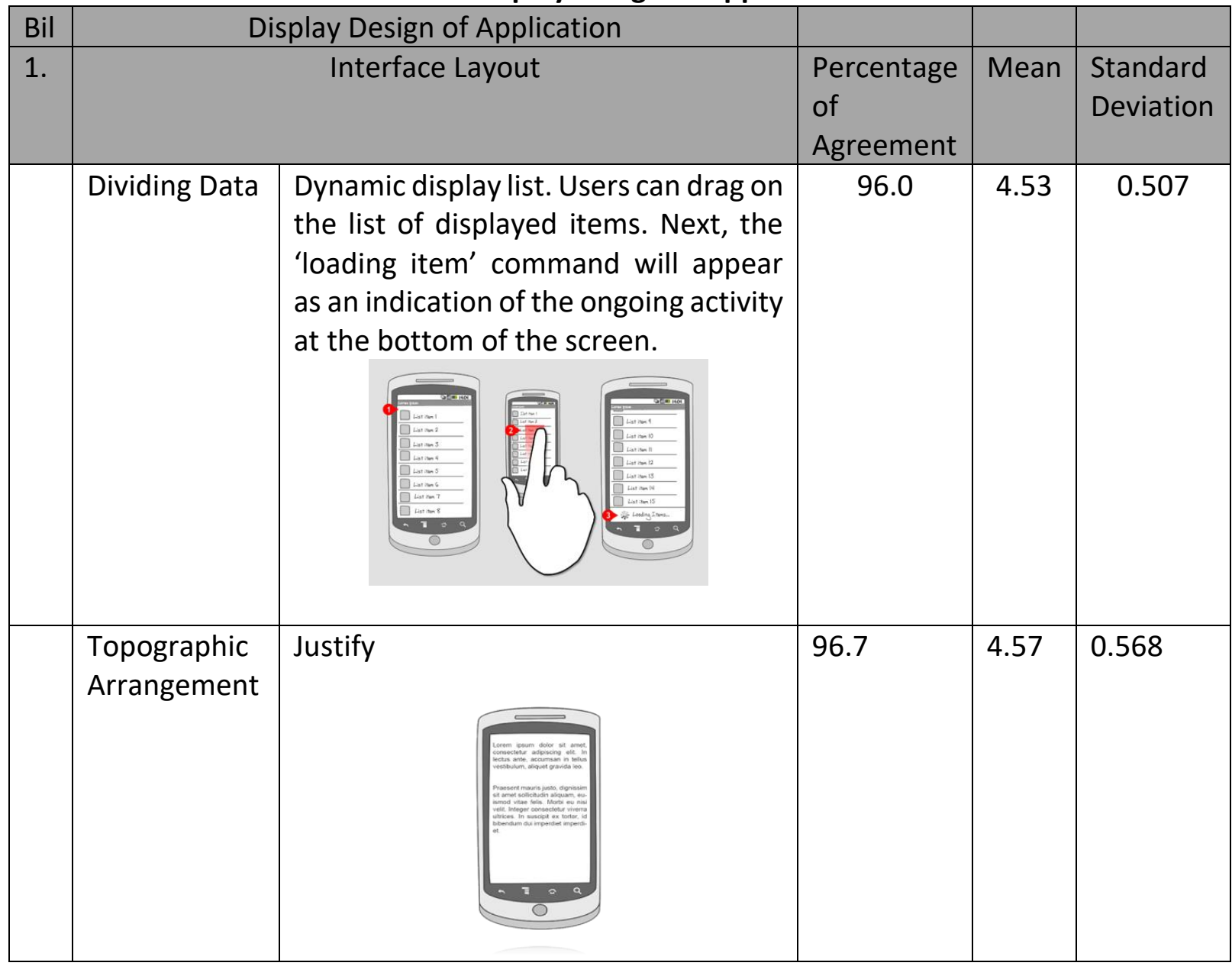




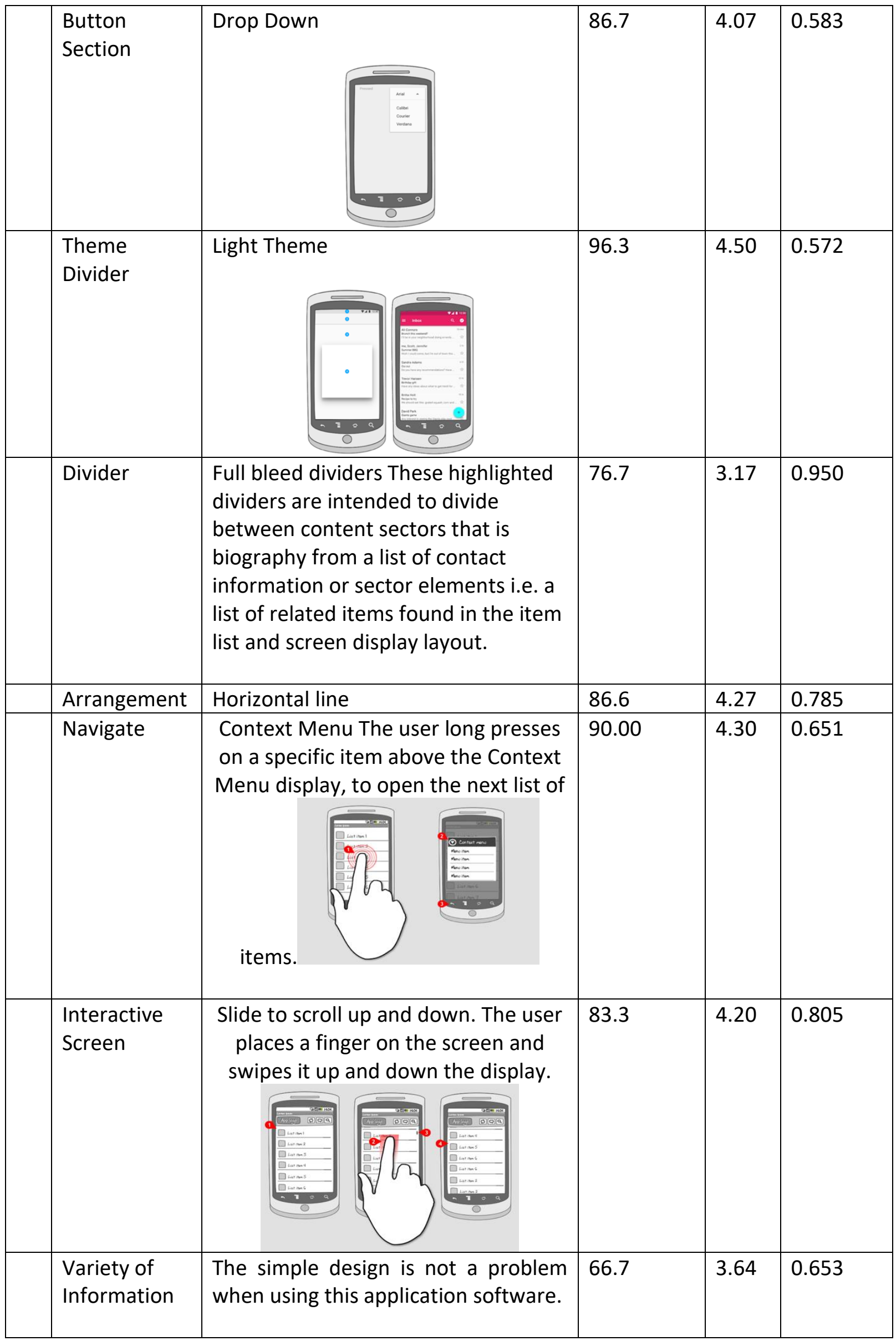




\begin{tabular}{|l|l|l|l|l|l|l|}
\hline \multicolumn{1}{l|}{} & & & & & & \\
\hline \\
\hline
\end{tabular}

Findings from table II show the three main components in the design of application display namely the layout of the interface on the screen, colors and letters. The results found that the balanced topographic arrangement element recorded the highest agreement with mean value $=4.57 ; \mathrm{sd}=0.568$ or 96.7 percent. Followed by a bright theme divider element with mean $=4.50 ; s d=0.572$ or 96.3 percent, dividing data recorded mean value $=4.53$ and $s d=$ 0.507 or 96 percent, navigation element mean $=4.30$; $\mathrm{sd}=0.651$ or 90 percent, horizontal line layout element mean $=4.27$; $s d=0.785$ or 86.6 percent and followed by button part element mean $=4.07$; $s d=0.583$ or 86.7 percent. Moreover, seven designs involving aspects of interface layout on mobile application screens have exceeded more than 80 percent agreement and only one element found to be below the 80 percent which is the multi information element. The findings of this study are also supported by Mukti (2000) who agrees that human learning and understanding can be enhanced through interactive means. The same view of the study is supported by Miswan and Adnan (2015) that highlights multimedia technology and multi-touch screen as the main features that increase children's interest to keep exploring. While peripherals with elements of appealing interface layout and interactive features can help to increase students' understanding in pillars of solah as well as 
to improve their fluency in recitations of prayer, thus giving them the confidence to practice prayer obligation.

All items measured in the study recorded a high level of agreement. Thus, the results strongly suggest the presence of elements such as simple screen, audio, video, graphics, fonts or writing, color, navigation, graphics, animation, video, descriptive sentences and menus should be included in the development of mobile applications. The combination of aforementioned elements results to engaging mobile application that suits the needs of students. As for the presentation preparation stage, the findings revealed that students need a suitable and simple screen, easy -to -read fonts, bright colors, attractive graphics, appropriate animations, audio and video sign language, sentence descriptions, menus and option buttons. This finding is also in line with the study of Pajuzi (2018) that the features presented in the application is created based on the students' needs analysis to ensure that the software is fully developed to meet their learning needs. Findings on the interface in the application software that contains key elements such as screen background, windows and panels, buttons and control icons, text, graphics, audio, video, animation and as well as the interface design process involves the production of displays for user viewing. The design then should focus on the needs of the users rather than following the preferences of the designer or software developer, which is similar to the study of Mamat et al., (2020). Furthermore, text -based instructions on small screen displays should be clear and concise. Navigation instructions on the context menu are simple and compact along with attractive images as mentioned by Ali (2014) that address images help to minimize cognitive load because attractive images can improve memory compared to using text alone. Appropriate color and text selection is supported by visual elements as in the similar research work by Razalli et al (2015) that although children cannot read instructions on the screen, they can still interact with the screen and understand the instruction texts with the supported audio and color elements for text, topography and attractive data dividers.

\section{Conclusion}

The design of content -based mobile applications in Islamic Education subject is very helpful for students with hearing impairment and the deaf for the purpose of performing 'ibadah of prayer. The application design that features PWD -friendly-technology will attract and keep the interest of its users on the contents delivered. Additionally, the ICT based approach helps to share the knowledge of i'badah that is apppealing to the users and more importantly delivered in an effective and systematic manner.

\section{Acknowledgement}

This research has been carried out under Fundamental Research Grants Scheme (FRGS/1/2018/SSI09/UPSI/02/6) provided by Ministry of Education of Malaysia. The Authors would like to extend their gratitude to Sultan Idris Education University (UPSI) for their assistance in managing the grants.

\section{Corresponding Author}

Associate Prof. Dr. Nordin Mamat

Associate Professor Department of Early Childhood Education Faculty of Human

Development Universiti Pendidikan Sultan Idris Perak Malaysia

Email: nordin@fpm.upsi.edu.my 


\section{References}

Ahmad, L. H. (2014). Persepsi Pelajar terhadap kurikulum Pendidikan Islam Politeknik dalam Pembentukan sahsiah Muslim. Jurnal Pendidikan Malaysia 39(2) 133-140.

Ali, S. (2014) IcT the media (internet) and development: Malaysia experience. The Innovation Journal: The public Sector Innovation Journal.15(1).1-5.

Alvarez, C., Alarcon, R., Nussbaum, M. (2011). Collaborative Learning Activities In The Classroom Supported By One-To-One Mobile Computing A Design-Based Process. J. Syst. Softw. 84, 1961-1976.

Aunola, K., Leskinen, E., Nurmi, J-E., (2006) Developmental dynamics between mathematical performance, task motivation, and teacher's goals during the transition to primary school. British Journal of Educational Psychology 76 (1) 21-40.

Awang, P., Nordin, N. M., \& Muslimin, M. S. (2017). m-KBAT. Proceeding The International University Carnival On e-Learning (IUCEL). 206-207.

Budoya, C. M., Kissake, M. M., \& Mtebe, J. S. (2019). Instructional Design enabled Agile Method using ADDIE Model and Feature Driven Development Process. International Journal of Education and Development using Information and Communication Technology (IJEDICT) 15(1) 35-54.

Embi, M. A. (2016).Pemikiran dan Reka Bentuk Semula Pengajaran dan Pembelajaran Abad Ke-21, UKM Bangi Selangor. Retrieved from http://www.youblisher.com/p/1530964Pemikiran-dan-RekaBentuk-Semula-Pengajaran-dan-Pembelajaran-Abad-ke-21/

Ferati, M., Pfaff, M. S., Mannheimer, S., \& Bolchini, D. (2012). Audemes at work: Investigating features of non-speech sounds to maximize content recognition. International Journal of Human-Computer Studies, 70(12), 936-966. doi:10.1016/j.ijhcs.2012.09.003

Forest, E. (2014). The ADDIE Model: Instructional design. Educational Technology website, Framework and Theories. http://educationaltechnology.net. [9 Mac 2018].

Guardino, C. (2015). Evaluating teachers' preparedness to work with students who are deaf and hard of hearing with disabilities. American Annals of the Deaf, 160(4), 415-426

Guardino, C. (2015). Evaluating teachers' preparedness to work with students who are deaf and hard of hearing with disabilities. American Annals of the Deaf, 160(4), 415-426

Guardino, C. (2015). Evaluating teachers' preparedness to work with students who are deaf and hard of hearing with disabilities. American Annals of the Deaf, 160(4), 415-426

Guardino, C. (2015). Evaluating teachers' preparedness to work with students who are deaf and hard of hearing with disabilities. American Annals of the Deaf, 160(4), 415-426.

Harun, J., \& Tasir, Z. (2003).Multimedia Dalam Pendidikan.PTS Publication.Bentong.

Ibrahim, A. (2017). Pembangunan Modul Pembelajaran Seni Reka Grafik Berasaskan Teknologi dan Gaya Pembelajaran Pelajar Bermasalah Pendengaran. Tesis Dr. Fal, Fakulti Pendidikan, Universiti Malaya.

Ismail, R., Samsudin, S. N, Sulaiman, A. W., Zainol, N., \& Zaid, D.S. (2016). Kajian Literatur Terhadap Aplikasi Mudah Alih Berunsurkan Islam (Literature Review On The Islamic Mobile Apps). Journal of Global and Sosial Entrepreneurship (BGSE) Vol.: no.5 (2016) page174-182. elSSN 24621714.

Jamil, M.R.M., Saedah Siraj, Hussin, Z., Nor, N.M.\& Sapar. A.A. 2017. Pengenalan Asas Kaedah Fuzzy Delphi Dalam Penyelidikan Rekabentuk Dan Pembangunan. Selangor: Minda Intelek Agency.

Kätsyri, J., Ravaja, N., \& Salminen, M. (2012). Aesthetic images modulate emotional responses to reading news messages on a small screen: A psychophysiological 
investigation. International Journal of Human-Computer Studies, 70(1), 72-87. doi:10.1016/j.ijhcs.2011.08.00

Mamat, N., Kamarudin, K., Ali, S. R., \& Noh, N. M. (2020). The Integration of Information and Communication Technology (ICT) in Teaching and Learning in Government and Private Preschools in Malaysia. International Journal of Academic Research in Business and Social Sciences. 10(11), 104-112

Md. Salleh, S., \& Rahman, N. A. (2010). Pembangunan Modul 'Panduan Pemilihan Kombinasi Warna Bagi Rekabentuk Skrin Dalam Pembangunan Aplikasi Multimedia Dan Laman. Universiti Teknologi Malaysia. pp. 1-9. (Unpublished) http://eprints.utm.my/id/eprint/10985/.

Mayer, R. E. (2014). Incorporating motivation into multimedia learning. Learning and instruction. 29, pp. 171-173. doi:10.1016/j.learninstruc.2013.04.003.

Miswan, M., \& Hamedi, H.M. (2015). Pembangunan aplikasi peranti mudah alih untuk kemahiran membaca kanak-kanak: Aplikasi Literasi LINUS (LiLIN). Jurnal Pengajian Media Malaysia, Vol. 17(2), 64-78

Mukti, N. A. (2000) Computer Technology in Malaysia: Teachers' Background Characteristics, Attitudes and Concerns. Electronic Journal of Information Systems in Developing Countries 3(8)1-13. Doi 10.1002/j.1681-4835.2000.tb00022.x

Mubarakfuri, S. R. (2010). al-Raheeq al-Makhtum, Bahs Fi al-Sirah al-Nabawiah. Arab Saudi: Dar al-Wafa' Li alTiba'ah wa al-Nasyri wa al-Tauzi' al-Mansurah.

Nawi, A., \& Hamzah, M. I. (2013) Tahap penerimaan penggunaan telefon bimbit sebagai Mpembelajaran dalam Pendidikan Islam. JIAE: Journal of Islamic and Arabic Education, 5 (1). pp. 1-10. ISSN 1985-6236

Razalli, A. R., Ibrahim, H., Selamat, S., Salleh, N., \& Abdullah, M. A. (2015). Penggunaan Model Pengajaran Berasaskan Bahasa Isyarat (MOPBIS) dalam Pengajaran Bahasa Melayu Murid Pekak. The Asean Journal of Knowledge Contribution. 3, 53-60.

Richey, R. C., \& Klein, J. D. (2005). Developmental research methods: Creating knowledge from instructional design and development practice. Journal of Computing in Higher Education, 16(2), 23-38.

Restituyo, C. A., Loizides, F., Yang, S., Weir, K., Worrallo, A., Hartley, T., Souleles, N., Loizou, M. (2017) Presenting and Investigating the Efficacy of an Educational Interactive Mobile Application for British Sign Language Using Hand Gesture Detection Techniques. In Proceedings of the 16th World Conference on Mobile and Contextual Learning, Larnaca, Cyprus, 30 October-1 November 2017

Said, C. S., Umar, I. N., Muniandy, B., Desa, S. (2015) Aplikasi Teknologi Multimedia dalam Pembelajaran Sains Biologi: Kesan Terhadap Pelajar Berbeza Tahap Keupayaan Spatial. Journal of ICT in Education (JICTIE) ISSN 2289-7844 / Vol. 2 / 2015 / 15-25

Shraim, K. (2019). Mobile Apps Criteria for Guiding STEM Teachers in Developing Mobile Learning Activities. International Journal of Progressive Research in Education 2(2): 139148.

Shaharuddin, M. S., \& Rahman, A. N. (2010). Pembangunan Modul 'Panduan Pemilihan Kombinasi Warna Bagi Rekabentuk Skrin Dalam Pembangunan Aplikasi Multimedia Dan Laman. Universiti Teknologi Malaysia. pp. 1-9. (Unpublished) http://eprints.utm.my/id/eprint/10985/.

Siraj, S., Alias, N.,Witt, D. D., \& Hussin, Z. (2013). Design And Developmental Research : Emergent Trends Educational Research. Kuala Lumpur. Pearson Malaysia Sdn. Bhd. 
Sharples, M., Corlett, D. and Westmancott, O. (2004). The Design and Implementation of a Mobile Learning Resource. Personal and Ubiquitous Computing, 6, pp. 220-234

Samsudin, G. Y., \& Yaacob, E. S., \& Richard, M. (2012). Affective impact of navigational and signaling aids to e-learning. Computers in Human Behavior, 28(2), 473-483.

Sidek, S. F., Fathil, N. S., Zain, N. Z. M., \& Muhammad, K. (2014). Pembangunan Perisian Kursus 'Saya Suka Belajar' Untuk Pembelajaran Bahasa Melayu Bagi Kanak-kanak Autisme. Malay Language Education Journal. Fakulti Pendidikan, Universiti Kebangsaan Malaysia. 4 (1). pp. 1-10. ISSN 2180-4842.

Ujang, A. (2016). Pembangunan Modul Pembelajaran WebQuest Pendidikan Kesihatan untuk Guru Pelatih Murid BermasalahPembelajaran. Tesis Dr. Fal, Fakulti Pendidikan, Universiti Malaya.

Vilamil-Casanova, J., \& Molina, L. (1997) Multimedia Production, Planning and Delivery. New York: Pearson

Wyche, S. P., Caine, K. E., Davidson, B., Arteaga, M., Grinter, R. E. (2008). Sun Dial: Exploring Techno-Spiritual Design through a Mobile Islamic Call to Prayer Application. In CHI 2008 Proceedings, pp. 3411-3416. Florence, Italy

Yasin, M. H. M., Tahar, M. M., Bari, S., \& Manaf, F. N. (2017). The Sign Language Learning in Deaf Student and Special Education Teacher in Integration Program of Hearing Problem. Journal of ICSAR 1(2): 166-174.

Zainuddin, A. (2017). Kesan bimbingan kelompok menggunakan modul kesejahteraan diri mualaf (MKDM) terhadap kesejahteraan diri di Selangor. Tesis Dr. Fal, Fakulti Pendidikan, Universiti Kebangsaan Malaysia. 